\title{
Visions of Finland in the Age of Globalization
}

\author{
Competition State or a Fair and Responsible Nation? ${ }^{1}$
}

\author{
Lotta Lounasmeri
}

\begin{abstract}
It seems that in the current era of globalization, the national discourse has not lost its appeal in Finnish public discussion. Somewhat paradoxically, it is as strong as ever when the challenge of globalization is being debated in the Finnish press. A closer investigation of the national arena Helsingin Sanomat (HS) shows a coalition of powerful societal actors in the centre, building up a national consensus and a vision of Finland's future as a competition state. Different interest groups are divided in their attitudes towards globalization and its implications for Finnish society. Less powerful actors see it as a threat and try to bring forward a vision of Finland as a fair and responsible nation. At the same time, mainstream journalism seems to be afraid of political conflict and of stirring things up. Instead, the paper holds on to the traditional consensus-oriented public discussion culture. The present article discusses the Finnish globalization discussion from the 1990s until 2004.
\end{abstract}

Keywords: conflict, consensus, elites, globalization, journalism, public discussion

\section{Introduction}

Developments in the global, European and Finnish political, economic and cultural environments since the beginning of the 1990s can be seen in the background of the Finnish globalization discussion. Globalization is one of the key concepts around which the political discussion and struggle concerning these changes has evolved. It has become a buzzword and a building block in creating a vision of Finland's future. The traditional consensus between different interest groups in Finland would seem to be in a state of change. However, the nature of Finnish public discussion as historically restrained, careful and consensus-seeking does not show signs of transformation. By the same token, it must be stated that globalization as a subject is rather challenging and not easily approachable for journalism, especially as the dominant practices in journalism do not support in-depth treatment.

In the Finnish context, the national newspaper Helsingin Sanomat provides interesting material for a researcher of power, as it is a nationally visible and important arena for discussion and debate on societal changes and conflicts. As an exerciser of power, the media should not be seen as one lump, but we should recognize that different media are in very different positions (Ahlfors et al. 1995: 53). In the Finnish media field, Helsingin 
Sanomat has an undisputable position of power: It represents the biggest news corporation, SanomaOYJ, and is by far the biggest newspaper, with a circulation of $397.838^{2}$.

The empirical material has been analysed using the method of critical discourse analysis. Social constructionism and the discourse analysis associated with it represent a methodology that sees reality as socially constructed and communication as a mode of social action. Consequently, the media do not function as windows to reality, but rather represent versions of it. Törrönen (1997: 221-247) has studied news and scientific texts as semiotic macro structures that construct narratives and stories. These stories function as persuasion and motivate the public or audience to act. They are discursive structures that do not only describe or define the world, but also work towards changing it to fit the vision or goal presented. This kind of discourse analytical approach has also been used in the analysis of the media texts in question. The globalization debate is viewed as a struggle over definitions between different actors in society: whose definitions will predominate? The discursive images of Finland that are being built and the actors building them are analysed. Moreover, journalism is viewed from the angle of political discussion as well as the exercise of power.

Evaluating discourse analysis is not very simple on the traditional terms of reliability and validity. Compared to traditional measures of reliability, discourse analysis emphasizes the researcher's position as an active interpreter and also as a participant in the discussion of the research subject (Juhila 1999: 201-231; Willman 2001: 81). The approach involves a rigorous analysis of conventional modes of speaking, and through this providing meaningful interpretations of certain phenomena. This entails detailed classifications of the data and illustrations of the analysis using original, representative passages of text as evidence of the interpretations (Potter \& Wetherell 1987: 172-173; Eskola \& Suoranta 1998: 61).

In the discussion analysed, a vision of the Finnish nation's future is being created discursively. Globalization sets this story in motion: As an external threat or opportunity, it obligates the Finns to act as a nation. The idea that globalization requires us to act as a nation (nationalistic discourse) as well as a humankind (global discourse) is not contested by any actors in the paper. The direction in which the nation should be going is, however, under contention. I refer to this direction as the vision of the nation's future. In the present article, I present the dominant vision as well as the one challenging it.

Next, I will discuss globalization as a political concept and object of discursive struggles. I will also look at journalism as an arena of societal struggles and political debate in democracy and as an exerciser of power. Second, I will problematize the nature of Finnish public discussion. Third, I will discuss the changes brought by the globalizing tendencies in Finnish society. The theoretical section aims at grounding and informing the empirical analysis, which focuses on the progression of the globalization discussion and the visions of Finland promoted by the different coalitions. Finally, I will consider the role of journalism as the organizer of the discussion.

\section{Analysing Globalization as a Political Concept}

By the end of the 1990s, globalization had become one of the most popular concepts in analysing contemporary society, and it has been seen simultaneously as an opportunity and a threat to democracy and welfare. Globalization as a worldwide phenomenon 
is most commonly associated with the capitalistic market economy system based on free trade agreements, which result in the enlargement and intensification of economic interaction beyond nation-states. In my view, globalization should be considered as a political concept used for different purposes instead of a neutral one describing a societal phenomenon. Hay and Rosamond (2002: 151) see it as a cognitive filter, frame or conceptual lens through which social, political and economic developments can be ordered and made intelligible.

As such a concept, globalization has been the object of discursive struggle over creating social imaginaries about our future, our possibilities and our choices. Social imaginaries are related to power: Who has the power to define or imagine what society could be like? An imagined community refers to imagining what a society is and who the people in it are. The political life of modern nations is strongly built on imagined realities and communities (see Anderson 1991: 14-49).

To trace societal changes or the evolution of discursive struggles, Laclau and Mouffe (1985) suggest studying the public sphere and public spaces as sites of struggle. The public space created by journalism is occupied by different institutions, groups and discourses engaging in a struggle over social reality. As a practice, journalism is at the same time limiting and enabling, because it offers different possibilities to different actors depending on their discursive resources and institutional position (Väliverronen 1993). Thus, the power of journalism is in how it treats the different actors participating in the discussion, how it sets the agenda and frames the discussion. Discursive power in journalism is also used by its powerful sources, because they get to speak in the newspaper.

One of journalism's traditional roles has been to facilitate and arrange public discussion. In the present article, the viewpoint is that democracy needs genuine political discussion and struggle in the public to stay alive (see Kantola 2002b: 264, 268). Thus, societal questions like globalization should be represented as political: The differing viewpoints and alternative solutions and the actors supporting them should be brought out into the open for public discussion. Real debate and conflict can also arouse more interest in public discussion (Olsen 1996: 199).

In order to facilitate democratic discussion, one should pay attention to power and power relations in communication in the spirit of the Foucauldian tradition (see Flyvbjerg 2001: 97-98). According to Foucault, political struggle in the modern exercise of power is above all a struggle over truth and dominant interpretations (Foucault 1980: 131; Foucault 2000a: 119-133). To understand the modes of modern political power, one should analyse the forces and counter-forces moving in a certain time and space, and the exercise of power shaped by these (Foucault 1978: 87-89; Foucault 2000b: 326-348; Kantola 2002a: 27). For researchers of power, communication is more about rhetoric and promoting interests than about freedom from positions of power. Legitimacy is achieved rather through the practices of communication than through rational arguments about the substance (Flyvbjerg 2001: 94). All in all, a researcher of communication must take into account both the rhetorical, interest driven as well as the communicative, rationally argumentation side of things. Only through empirical analysis can one discover whether communication is founded on rational argumentation or predominantly on the exercise of power - or both. 


\section{Democracy Needs Political Debate and Public Conflicts}

Democracy has usually developed when different groups struggle long enough to realize that they cannot achieve complete power, and that making compromises is essential (Rustow 1970; Hirschman 1994: 209). Dubiel (1990: 125-143) argues that social conflicts themselves produce the valuable ties that keep modern democracies together. For example, feminists and environmental activists got their agenda to the public through power struggles and conflicts (which are typical of activism and societal change), not relying on rational consensus (Wapner 1994; Spinosa et al. 1997). According to a Foucauldian interpretation, marginalizing conflict is also marginalizing freedom, because the right to take part in power struggles and conflicts is part of it (Flyvbjerg 2001: 108). Societal progress is achieved as much through differences and overcoming them through conflict as through accomplishments. Keller considers that, in all important struggles, the issue is ultimately differing visions of the future. Loyalty towards common goals, however, does not exclude conflicts about how to achieve them (Keller 1991: 146).

When looking at public discussion from the angle of political debate, on the one hand, and from the perspective of the exercise of discursive power, on the other, the traditional nature of Finnish public discussion seems rather problematic: special features of Finnish discussion have been a certain ambition to achieve consensus as well as a homogenous climate of opinion, as the circle of powerful societal actors has been quite unanimous and small (see Kantola 2002a: 292-293). Next, I will discuss the changing Finnish society as shaped by its history as well as recent developments in marketization.

\section{Is Political Discussion Overshadowed by Consensus-seeking and the Market Logic?}

Finnish society and its power structures have experienced significant changes during recent decades. Building a national welfare state was high on the agenda of Finnish politics after the Second World War, and the state was given a significant role in building the society. Before the war, confrontation was a distinct feature of Finnish society, but afterwards contradictions were alleviated and the most important interest groups started building a consensus. Alasuutari (1996: 75, 77-78, 266) states that a shared cultural understanding of the nation-state of Finland arose, and it entailed a basic assumption of seeing the national economy as a corporation. However, along with changes in the international political and economic setting, a period of transition started in Finland in the 1980s. This has often been called a transition from a command economy to a competitive society or a competition state. These developments have all challenged the national power structures, ways of doing politics as well as the national Finnish culture (Heiskala 2006: 24, 29-30).

Finland's EU membership as well as joining the Euro has narrowed down the sphere of national politics, but also changes in the parliamentary system have made oppositional politics ineffective. In practice, the governmental coalition in power has been able to carry on with their politics for the full electoral period. In such a situation, it is difficult to achieve critical changes through traditional politics (see Ilmonen 2006: 129). Furthermore, in the Finnish party field, there are no extremes (see, e.g., Alapuro 1999: 111), and as a price for this consensus, one can see the mundane nature of everyday politics, the disappearance of ideological questions from decision-making as well as politics chang- 
ing into practical administration with seemingly no alternatives. These developments are also reflected in the Finnish public discussion and journalism.

As society is now being analysed through the logic of markets and competition, the belief in development through politics and negotiations between different interest groups has escaped the field of journalism as well. Luostarinen and Uskali (2006: 179, 189) state that the motives of journalism have changed more dramatically, as the media enterprises have become more and more profit oriented. The prolific commercialization of mass media is integrating journalism more and more into other commercial interests in society. In the everyday actions of the media, this development is seen in the intertwining of journalistic and commercial activities and agendas (Ruostetsaari 2003: 125).

It seems that public political discussion is being overshadowed by the market logic, on the one hand, and the traditionally weak discussion culture, on the other. This setting is interesting from the point of view of power. Consequently, Finnish communication scholars have put forward ideas that, in the Finnish society, powerful institutions and elites actually use the media to legitimate and renew their own power (Kantola 2002b: 270; Väliverronen 1993: 22). At any rate, given Finland's weaker civil society than in other Nordic countries and its thinner tradition of public discussion, Finnish elites have more room to operate in than do their neighbours (Ruostetsaari 2003: 309).

National unity regarding the guidelines of societal development has been a strength and has benefited Finnish society (Ruostetsaari 2003: 300-301). However, when it goes too far, consensus can turn into weakness, if the requirement for unanimity prevents the development of alternative visions or solutions. In Kantola's research (2002a: 210-211, 218) on the Finnish political elite, the political culture built on consensus actually turned out to be one possible factor contributing to the recession of the 1990s: The weak signals related to changes in the economy were not taken into account sufficiently, because the elites tried not to "rock the boat", as political tradition demanded. In the economic crisis of the 1990s, the public sphere did not function as an arena of political discussion, but instead a tight policy on publicity arose among the decision-makers. Also regarding EU membership discussions before joining in 1995, the political elite was almost unanimously behind membership and saw the public sphere as a danger that might hamper the manageability of the EU process (Heikkilä 1996: 69-71). In the public discussion on the EU referendum, alternative views and discussion were modest (Kivikuru 1996). After the collapse of the Soviet Union, the political atmosphere in Finland changed, but this has not affected the political culture as much.

Next, I will present my empirical analysis of the discussion on globalization in Helsingin Sanomat. The role of journalism will be analysed on two points: How does it appear as an arena of political discussion in the competition-driven atmosphere? Is the traditional spirit of consensus visible in the discussion?

\section{From a Global Economic Challenge to a Domestic Political Issue: Globalization Entering the Finnish Public Scene}

A system-oriented discourse, which sees globalization as an economic problem or challenge, has gained a strong foothold globally as well as in Helsingin Sanomat. This discourse is connected to a widespread discourse of economic globalization, which is also called the neoliberal globalization discourse (see Fairclough: 2003). Here the meaning 
of globalization is reduced to connecting all the world's societies into the same social and production system, which is based on global capitalism (see Mattelart 2002: 593). This discourse comes close to an idea that Beck (1999: 43) calls "globalism", where all the other dimensions of globalization - ecological, cultural, political and societal - are subordinate to the global market system, and where the basic difference between politics and economics is erased.

As the dominant subjects in the discussion on globalization over the years (19922004), one can find the changing operational environment of nation-states and companies as well as their competitiveness, international negotiations on free trade, and political and social systems in the era of globalization. A long process was required before globalization would effectively enter the national sphere of things and the complex of problems of Finnish society. Discussion around the term began to pick up in 1998-1999. The number of stories per year is presented in Table 1 .

Table 1. Stories Containing the Word 'Globalization' Between 1992-2004 in Helsingin Sanomat

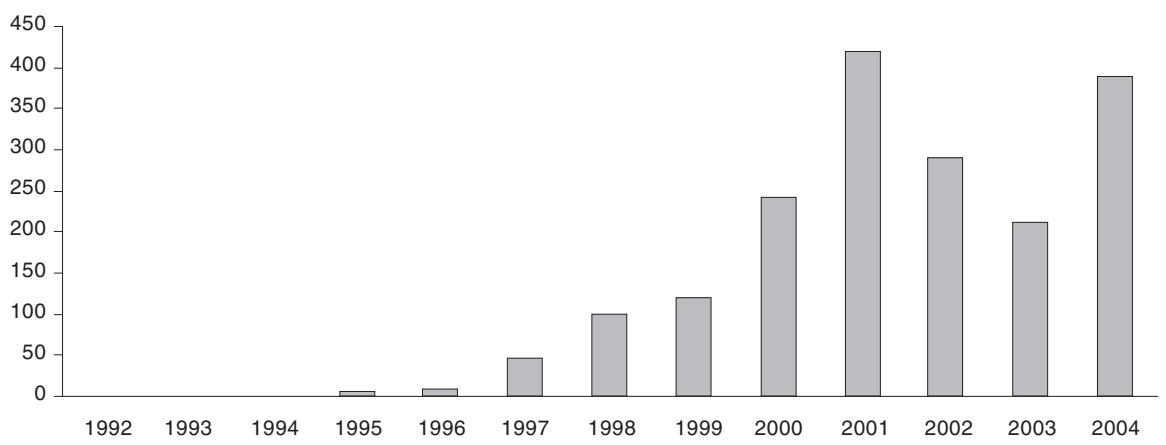

In the first phase of the discussion, until the turn of the millennium, globalization was represented as "a new" phenomenon and an economic challenge. The economy section of the paper dominated the discussion. Those participating in the discussion were mostly politicians, officials, academics and journalists themselves. In Table 2, the sections of the paper with the largest number of stories are presented:

Table 2. Sections with the Most Stories Including the Word 'Globalization' in Helsingin Sanomat

\begin{tabular}{|c|c|c|c|c|c|c|c|c|c|c|c|c|c|c|}
\hline $\begin{array}{l}\text { Section of } \\
\text { the paper }\end{array}$ & 1998 & $\begin{array}{c}\%- \\
\text { share }\end{array}$ & 1999 & $\begin{array}{c}\%- \\
\text { share }\end{array}$ & 2000 & $\begin{array}{l}\%- \\
\text { share }\end{array}$ & 2001 & $\begin{array}{c}\%- \\
\text { share }\end{array}$ & 2002 & $\begin{array}{c}\%- \\
\text { share }\end{array}$ & 2003 & $\begin{array}{c}\%- \\
\text { share }\end{array}$ & 2004 & $\begin{array}{c}\%- \\
\text { share }\end{array}$ \\
\hline Culture & 18 & 18,2 & 18 & 15,0 & 24 & 10,0 & 49 & 11,7 & 39 & 13,4 & 29 & 13,7 & 38 & 9,7 \\
\hline Editorial page & 17 & 17,2 & 18 & 15,0 & 37 & 15,4 & 51 & 12,2 & 29 & 10,0 & 27 & 12,8 & 80 & 20,5 \\
\hline Letters to the editor & 6 & 6,1 & 10 & 8,3 & 24 & 10,0 & 58 & 13,8 & 17 & 5,9 & 19 & 9,0 & 39 & 10,0 \\
\hline Economy & 30 & 30,3 & 35 & 29,2 & 49 & 20,3 & 42 & 10,0 & 25 & 8,6 & 27 & 12,8 & 50 & 12,8 \\
\hline Foreign affairs & 11 & 11,1 & 10 & 8,3 & 46 & 19,1 & 85 & 20,3 & 64 & 22,1 & 26 & 12,3 & 26 & 6,7 \\
\hline Leisure & 0 & 0,0 & 0 & 0,0 & 4 & 1,7 & 14 & 3,3 & 15 & 5,2 & 9 & 4,3 & 10 & 2,6 \\
\hline Sunday pages & 5 & 5,1 & 5 & 4,2 & 8 & 3,3 & 23 & 5,5 & 20 & 6,9 & 21 & 10,0 & 18 & 4,6 \\
\hline Domestic news & 9 & 9,1 & 12 & 10,0 & 25 & 10,4 & 47 & 11,2 & 51 & 17,6 & 31 & 14,7 & 81 & 20,8 \\
\hline Total & 99 & & 120 & & 241 & & 419 & & 290 & & 211 & & 390 & 1770 \\
\hline
\end{tabular}


In the second phase (2000-2002), voices critical of globalization started to be heard in the paper, and the positive nature of globalization was being contested. In 2001, the globalization protests received the most public attention, and this is seen in the foreign news section, which had the greatest number of stories on the subject. The situation stabilized in 2003, with economy, foreign news and domestic news publishing about the same number of stories. The criticism was brought on by the anti-globalization movement and its domestic and international representatives. The critique spread very quickly from informal and marginal actors to the political core and conventional politics, becoming part of the vocabulary of society (see also Lindholm: 2005, 22, 178). Lindholm (2005: 159-160) considers that politicians used the globalization debate as a way to gain publicity and present themselves as "speakers for the people". It seems that the political actors presenting critique were outside the actual circle of power.Even if this criticism did result in the discussion becoming more political and value-oriented (see also Lindholm 2005: 207), it did not change the consensus-seeking nature of it.

In the third phase, towards the end of the data collection period, the domestic news section took over the subject, publishing the greatest number of stories in 2004. Globalization became part of domestic politics, and the paper reported on labour market negotiations and the Finnish strategy in the globalizing world.A national story and a dominant vision of Finland began to take shape.

This national story obligates Finns to work for the future that is being laid out before them. A coalition of the powerful promotes this "competition state" vision. Other, less powerful actors in society express concern for global and national welfare and try to develop an alternative vision for Finland: the "fair and responsible nation". The discussion can also be seen as a definition process: What are the implications of globalization for Finnish society?

\section{The Pro-globalization Coalition and the Outsiders}

In the Finnish discussion on globalization, different fields in society as well as traditional interest groups form new coalitions, and the group of the powerful dominating the discussion becomes visible. Taking part in the exercise of power seems to explain the discourses and their differences more than, for example, the political or party-political viewpoints of the actors (see also Kantola 2002a). Positive attitudes towards globalization are typical of those with an institutional position and a possibility to exert real influence and power. By the same token, those more critical of globalization seem to be less influential and have fewer possibilities to make an impact on policy decisions. A coalition in support of globalization and the vision of Finland as a competition state can be found around a "power group".

Not all of those who have a traditional institutional position in society are included in the globalization coalition. The position of the President and MPs as well as that of the trade union movement is more one of a challenger than a member of the established coalition. It seems that their position in present-day Finland has changed: They no longer represent the core of power.At the same time, new actors are coming to the core: The Prime Minister and party leaders seem more powerful than before, the various representatives of business life are strengthening their position and the state officials in national and EU-level are setting guidelines for the nation's development. In the present article, 
the focus is on the roles of representatives of political power, employers and employees, academic researchers and NGOs in the globalization discussion. Next, I will take a look at these groups in relation to their roles in contemporary Finnish society.

\section{Concentrated Political Power: Government in the Centre}

In the public discussion on globalization, it is noteworthy that big party leaders and ministers regard globalization more positively than the MPs (esp. Social democratic ones) and representatives of small parties do, and they unanimously back the idea of Finland as a competition state.

The Finnish government sees globalization as "mainly inevitable as well as a positive trend". Finland has benefited from globalization and continues to benefit from it. (Reporter Jaakko Hautamäki about the government's brief, HS 20.6. 2001)

As the rightwing and centre parties are most pro-globalization, those representing different views inside these parties have become marginalized. The ex-party leader of the National Coalition Party, Ville Itälä, and MP, ex-minister Sirpa Pietikäinen, differ from the mainstream with their talk of an uncontrollable globalization that restricts democracy.

According to Itälä, one cannot look at globalization in black and white: it enhances welfare and peace, but as it is uncontrollable it can restrict democracy. The National Coalition Party should discuss the question and take a stand in one year's time, Itälä suggested. (Leader of the National Coalition party Ville Itälä, HS 11.6. 2001)

... she has pondered on the Pandora's box of globalization and has always run into the same thing: the crisis for democracy. Economic power has broken away from the control of people and started to live its own life as a tyrant. (Reporter Saska Snellman quoting the MP of the National Coalition Party Sirpa Pietikäinen, HS 9.12. 2001)

The picture that becomes visible in this discussion can be seen in light of changes in the political and economic operating environment. Political power in Finland has experienced a tendency towards concentration (see Väyrynen 1999: 37). The position of the government is central, and has been strengthened by changes in the parliamentary system and its position in EU politics. EU membership in general has diminished the power of national political bodies in Finland. The parliament has become somewhat marginalized, as politics is carried out at the EU as well as global level. Due to globalization, other tendencies are the growth of the influence of markets and state bureaucracies that prepare legislation. The President's power has been diminishing in Finland since the 1990s.Instead, the Prime Minister has become, with increasing clarity, the political leader of Finland (Ruostetsaari 2003: 85-86; Mattila 2000: 148; Paloheimo 2002: 207, 218). This has also strengthened the position of big party leaders.

\section{Employers and Employees: Change in the Balance of Power?}

In the globalization discussion, Finnish employers present their points of view vigorously, while the trade union movement appears more as a bystander, commenting cautiously and only infrequently. 
The growing influence of business life in Finnish society cannot be seen straightforwardly in the globalization discussion, as private sector actors seem to be acting more behind the scenes than as active public speakers. It has been brought up in media research (Davis 2002: 50) that corporate sources are not very effective in gaining access to mainstream news. Furthermore, companies have discovered that political goals are not achieved by trying to influence public opinion. Rather, it is more effective to interact directly with the political elite than to use the news media, which is potentially hostile, unpredictable and imprecise. In the data, a few high level executives establish themselves as messengers of globalization and its blessings. The leaders of Elcoteq, Nokia and Sampo Bank bring forward the viewpoints of the globalizing companies.

In the words of Ollila, globalization is a much bigger challenge to society than it is to the companies that have already adapted themselves to it. At the same function, the CEO of the Sampo Corporation Björn Wahlroos also emphasized the readiness for change, and the importance of being able to adjust to the changing environment. (Chief editor Janne Virkkunen quotes the CEO of Nokia Jorma Ollila and the CEO of Sampo Corporation Björn Wahlroos, HS 31.10. 2004)

Otherwise the interests of the corporate sector are represented by the employers' organizations, especially in 2004, when they are active in challenging the current labour market system in order to respond to the challenges of globalization. In the same year, a national think-tank, Finnish Business and Policy Forum, EVA, announces its strategy for the Finnish nation.

Finland is such a small country that our part in the globalizing world is to adjust. It is not possible to isolate oneself, warns the future number one man of the Confederation of Finnish Industries EK, Leif Fagernäs. "There are limits to national politics, because the competition is already here. It concerns also services and the labour markets, whether we like it or not". (Head of Industry and Employers Leif Fagernäs, HS 23.3. 2004)

EVA demands strong leaders and cuts in taxation (Reporter Heli Saavalainen, HS 6.10. 2004)

Regarding the trade union movement, it is noteworthy that it does not seem to participate in the public discussion on globalization.It seems that employee organizations primarily participate in discussions that involve the concrete interests or benefits of the employees, but they do not bring forward many ideas on general policy issues or visions of the future. They are critical of globalization and try to bring alternative views to the discussion, but do so very cautiously and seek compromises. They do not seek to emphasize contradictions but common interests, and view co-operation with the corporate sector as inevitable for both parties involved. Global rules and common values are also of importance to them.

We would like to create the wealth together, not just share the results. Finland is such a small player in this fierce field of international competition. Even the self-protection instinct says that confrontations in working life should not be too big, so that we can work together to cope with the new challenges posed by globalization. (Head of SAK, Central Organisation of Finnish Trade Unions Lauri Ihalainen, HS 10.11. 2003) 
Employer and employee organizations should continue discussions. Finland needs an antidote to the negative effects of globalization. Investments and jobs in Finland must be secured. (Head of STTK, the Finnish Confederation of Professionals Mikko Mäenpää, HS 7.10. 2004)

All in all, the paper's role in the unions' passiveness should also be recognized. Why hasn't the paper found it necessary to involve the unions in the debate?The empirical material attests to the idea that the space for political action by old social movements like the trade union has been narrowed down (Ilmonen 1998: 26-27). While international capital becomes increasingly interconnected and crosses national borders, and globalization has created mutual interests between the multinational companies and their executives, this unity beyond national borders has not arisen among employees. On the contrary, employees in different countries are set against each other in the global competition for jobs (Etzioni-Halevy 1999: 240).

\section{A Divided Academia}

In the discussion, Finnish social scientists have taken the role of interpreting globalization and the changes it has brought about. Inside academia, they are by far the group that participates most in the debate. Their attitude towards globalization has been rather critical, more and more so as the debate has evolved.

Globalization is a contradictory issue. On the one hand, it accelerates growth of the economy and productivity, on the other, it has a tendency to compound inequality (Professor of Political Science Raimo Väyrynen, HS 16.2. 2001).

Governing globalization calls for an ethical order that respects human dignity. As we are dependent on each other, global politics is not idealism but realism, which enhances the welfare and safety of Finnish citizens. Unselfish sacrifice is not required, but understanding one's long-term self-interest (Professor of History Juha Sihvola, HS 5.5. 2004).

On the contrary, economists and engineers have joined the pro-globalization coalition. The benefits of globalization are often brought about by appealing to the economists, who themselves are not so active in the discussion.

Capital markets could not have functioned efficiently, had they not been allowed to globalize. Almost all economists agree that a significant proportion of the growth in welfare during the past two decades has resulted from the opening up of capital markets (CEO of the Sampo Corporation Björn Wahlroos, HS 18.4. 2001).

The views of social scientists are not used as arguments in the debate. The social sciences generally do not seem to play a prominent role in developed societies, neither in defining the political agenda nor in decision-making. The time span of decision-making has become shorter, and there seem to be no possibilities for analyses or research. As a result, social scientists and political decision-makers have grown further apart from each other (Lampinen 2002: 15, 21). 


\section{NGOs and the Anti-globalization Movement as Political Opposition}

The most visible actors from civil society in the Helsingin Sanomat debate have been the representatives of NGOs as well as the anti-globalization movement (also known as the global justice movement). They appear as a counter-force to the powerful proglobalization coalition, and try to promote an alternative vision of the future of Finland and the world. These actors became involved in the debate especially in 2001, when massive demonstrations and protests in connection with the meetings of international financial organizations were most visible for the public. These are the actors who are most critical of globalization, and who, in the first phase, are represented as objecting to globalization. Later on, these actors begin presenting themselves as supporters of an alternative globalization.

Mostly Nissinen does not talk about little fish, however, but big issues: globalization, predominance of the economy, old forests. "The economy no longer serves man, but is allowed to function on its own. Legislation is being dismantled around it. Opposition to this trend has to be taken up by the environmental organizations" (Secretary General of the Environmental Organisation Luontoliitto Jouni Nissinen, HS 5.8. 2000)

The idea that the consumer and the seller of products would meet in the market as equals and that the laws of demand and supply would define what is produced and how is also misleading. The central corporations of retail trade as well as multinationals control such a big part of the world economy that they are able to control supply and production. The advancement of economic globalization is thus under control, but it is happening in the interests of multinationals and the economic elite (Representative of the Fair Trade Organization inTurku Jyri Jaakkola, HS 23.5. 2001).

Even though involved in the discussion, these civil society actors get to speak considerably less and are much more controlled by journalists than are the political elite, who dominate the discussion. They have nevertheless taken the position of political opposition. The significance of media has grown in the strategies of new social movements, as they try to promote their activities in public (Ilmonen 1998: 30; Siisiäinen 1998: 228-229). Finnish activists interviewed by Jallinoja (2006: 90) stated that political decision-makers noted them if they had first gained public attention. By gaining publicity, the social movements have been able to bring new ways of thinking to public discussion and to try and establish these new ideas as alternative discourses to the dominant ones (Ilmonen 1998: 30). When this is viewed from a global perspective, for example, Schwartz and Lawson (2005: 284) have noticed that NGOs have started to replace political parties in creating connections between different societal actors. They create international networks and take advantage of international resources also in national struggles. This is also visible in Helsingin Sanomat, as many of the representatives of NGOs are international - almost half. The weight of these sources becomes rather great, as the paper reports the views of NGOs and protestors in connection with international demonstrations. Typically, the journalists report the protestors' views without actually letting them speak in the text. 


\section{Visions of a Better Finland}

The predominant vision presents Finland as a competition state, and the alternative vision presents it as a fair and responsible nation. The basic elements on which the coalitions build their arguments are presented in Table 3. All the parties are in favour of maintaining the Finnish welfare state, but the pro-globalization coalition strives to move on from the traditional, social democratic and regulated system to a market regime that is founded on an economically liberal society. The coalition argues that the system of welfare cannot be maintained without continuous economic growth.

Globalization is advancing in a controlled manner. Economies internationalize and create welfare for people.---And still there are demands in Western countries to restrain globalization. The trend can only be stopped undemocratically - by restricting people's creativity, controlling freedoms and regulating economic activities radically (Minister of Foreign Trade Kimmo Sasi, HS 16.5. 2001).

In contrast, co-operation, politics and fair rules are emphasized in the president's statement:

It is vital to Finland's success that it aims at actively building the rules of fair play in the world. "One has to proceed through co-operation in globalization", she says. Halonen calls for a new era of stronger politics, where international communities would co-operate better than they do now. According to her, the world should act for more responsible globalization (President Tarja Halonen, HS 14.3. 2004).

According to the pro-globalization coalition, the confrontations of Finnish society are over and everyone shares common interests and a common future. A coalition of challengers is setting itself against this group, and strives to present globalization as a conflict that needs to be reconciled, because interests are not common (neither the national nor

Table 3. The arguments of the two different visions are presented in this table, and they are related to the effects of globalization, on the one hand, and to the visions of a future Finland, on the other.

Coalition for the competition state Finland: prime minister, leaders and ministers of the 3 biggest parties, business life, majority of civil servants, academic economists and engineers

Globalization creates wealth Globalization enhances democracy In the end, everyone benefits from globalization Politics cannot solve the challenges of globalization, only markets can The world and Finland are united

Competitive Finland Wealthy Finland

Finland of individual freedom Flexible Finland
Coalition for the fair and responsible Finland: small parties, MPs (esp. Soc. Dem.), the president, minority of civil servants, NGOs and social movements, social scientists and humanists

Globalization threatens welfare Globalization threatens democracy

Many people suffer from globalization

Politics is needed to solve the problems of globalization

There are differing interests in the world and Finland

Fair Finland

Welfare Finland

Finland of shared responsibility

Safe Finland 
the global). National unity is undermined by various strategies, for example by pointing out those parties who do not benefit from globalization.It is argued that many people globally and in Finland have suffered from the consequences of economic globalization:

...new international pressures threaten to aggravate poverty again. Along with the globalization development, the differences in income inside and between nations grow and endanger balanced development (Leader of Council of Europe's Globalization Without Poverty campaign Mikko Lohikoski, HS 17.10. 1998).

The power coalition in turn argues that, in the end, everyone will benefit - only patience and more globalization are required:

Globalization has been positive for Finland. Moreover, the position of developing countries is most often best improved by connecting them to international markets, reckons the National Coalition Party. (Reporter Pekka Vuoristo about the National Coalition Party's White Paper, HS 9.6. 2002)

\section{The Competition State versus the Fair and Responsible Nation}

In the vision of Finland as a competition state, the world is seen as a global market system involving fierce competition with winners and losers. This discourse is associated with a global discourse of an economic market system, as stated earlier in the article. Finland wants to be a winner nation, and the people need to make sacrifices to achieve this. The role of the state is seen as one of enabling capitalism. This is manifested in a competition state that has adopted a corporate logic, and where the ideology of competition has spread to all sectors of society.In the competition state vision, Finland is presented as competitive, wealthy, flexible, innovative, efficient and productive, democratic and fostering individuality. Finland and the Finnish people need to be ready for constant reform and innovation in order to stay competitive:

Today's globalization and the heavy structural changes require strong co-operation from all the regional actors (Speaker of Parliament Paavo Lipponen about Finnish provinces, HS 16.11.2004).

In the vision of Finland as a fair and responsible nation, it is presented as emphasizing solidarity, welfare and common values, as well as employment and democracy. In this vision, continuity and preservation of the existing welfare structure are emphasized. Responsibility refers to social responsibility and community, and the duty of society to take care of its members and offer safety nets to those who need them. Fairness refers especially to creating fair and just global rules for everyone to play by.

Our task is to accomplish global rules of the game, which help to control, for example, the restless capital movements and the unemployment and insecurity they create." She calls it political naivety to believe that the liberalization of capital movements would create growth that at some point "oozes welfare for everyone (Presidential candidate of the Green League Heidi Hautala, HS 26.9. 1999).

Both visions tackle the questions of democracy and welfare essentially and both appeal to them as important values. In the power group's discourse, globalization enhances democracy and welfare, because it increases wealth and economic growth. The challenging 
coalition, on the other hand, sees globalization as a threat to democracy and welfare, because national actors are losing power and nobody seems to be assuming responsibility. According to this coalition, wealth, too, is accumulated very unevenly.

Another source of disagreement is who should make the rules of global competition and what they should be like. How much should we try to control globalization: Should we let the markets roam free or should we impose restrictions like the Tobin tax? In a nutshell: What should the role of politics be in the age of globalization? At the level of the national discourse, the question concerns how Finland should act in order to succeed and have a "bright future".

According to the pro-globalization coalition, the competition state Finland will be achieved by opening up to the world economy and adjusting the structures of society, as well as by investing resources in know-how and education, competitiveness and efficiency. The future vision cannot be achieved by resorting to the "old ways" of doing politics - they don't work anymore. The visionaries of the fair and responsible nation, for their part, try to establish a discussion on values: What is important and worth cherishing in Finland? What values should guide us while visioning the future? According to them, with the help of politics, the direction of globalization can be actively influenced and welfare state structures maintained.

\section{Conclusion: The Consensual Journalism}

The discussion on globalization carried on at the turn of the millennium in Helsingin Sanomat strengthens the notion that the predominant idea or vision of Finland as a competition state (see, e.g., Kantola 2002a; Heiskala 2006) has been widely accepted. Globalization is seen in the public as a competition system that is here to stay, and all one can do is prepare for it. Transitioning to a competition-oriented society has also occurred in reality, and the changes it has brought about are clearly visible in the research material, which shows that the traditional consensus and the positions of different interest groups in society's power structures are changing. This is not reflected, however, in the ways in which journalism operates: Even though the traditional consensus over Finland's future is not formed, journalism holds on to the culture of consensual public discussion. This also entails fading out conflicts that come to the surface.

A general trend in mainstream media seems to be that societal or political subjects are no longer dealt in depth. They are covered, but their political nature is obscured (Davis 2003: 671). This withering of politics and political discussion can also be seen in light of the material at hand. Political debate and questioning is avoided. Furthermore, the political opposition is not the first to challenge conventional or predominant ways of thinking, but instead it is the representatives of civil society who do so. One can see a sort of political apathy and politics turning into administration in the background. It is clear in this discussion that society's powerful aim at legitimizing their positions and renewing existing power structures, rather than stimulating discussion about political alternatives. Globalization's critics try to challenge the predominating vision by bringing conflict into the discussion. The paper for its part conforms mostly to the proglobalization coalition, at the same time marginalizing the different societal interests and the element of conflict inherent in them. The power elite and the paper seem to be creating an imaginary of a unified Finnish society, where there is no more confrontation 
and everyone shares the same interests. In this imaginary, the vision of Finland's future, too, is shared by all parties and actors. Marginalizing the elements of conflicts is done essentially by the elite coalition, which argues that we cannot resort to the "old ways" of doing politics (national welfare politics) in the face of the challenges of globalization. However, one should recognize that politics is essentially about making compromises between differing opinions and interests. Furthermore, the paper does not highlight the macro-level conflict produced by globalization, neither on the national nor global level. The conflict is rather blurred and marginalized, and at a point funnelled into the news about demonstrations and riots (2000-2002).

Helsingin Sanomat seems to be an outside observer and appears as a passive arena that maintains the status quo. It does not raise globalization as a major societal question. A comprehensive analysis of the changes in society or their significance is not presented. It is difficult to find real dialogue in the paper, as the different actors do not always genuinely confront each other. Helsingin Sanomat has neatly compartmentalized the globalization discussion; politicians appear in the politics section, business life in the economy section, representatives of cultural life as well as social scientists in the cultural section and so forth. It is not a question of "not telling it all", but a question of the story not leading anywhere - the paper does not ask questions or provide comprehensive analyses of societal developments. These problems are also connected to the traditional forms of journalistic representation, and cannot be solved very easily.

In relation to power, globalization is dealt with rather antiseptically: Power relations and hierarchies are set aside by talking about the interests of Finland as a nation, as well as global interdependency. The role and responsibility of society's powers that be are ignored, at the same time as the inevitability of global developments is emphasized. The globalization critique is directed to multinational corporations and financial institutions, not so much to national political bodies or representatives. When part of the national political elite - who seem to have fallen from the core of power- join the critics of globalization, the impression is that national decision-makers have no power over current developments. And still it is evident that national decisions have promoted and accelerated economic globalization. The changing role and problems of the legitimacy of politics today are not discussed. As the politicians strike a note that they do not have real power or possibilities to influence globalization development, they give their democratic power away by the same token. The paper also fails to hold politicians accountable.

All in all, in light of the present research material on the Finnish globalization discussion, it seems that Helsingin Sanomat as the national arena is not mainly an arena of political debate and deliberation, but rather ends up exercising its power as a medium by legitimating the actions and visions of the dominant pro-globalization coalition. In so doing, it also marginalizes at least to some extent democratic discussion.

\section{Final Remarks}

In spite of the globalization trend, one can still find alternative ways of representation and action in Finnish journalism and politics, as well as alternative future visions for Finnish society. Not all power has escaped our society, and the public discussion analysed here shows some of the forms it takes. Open discussion on power and major societal questions like globalization is essential to strengthening democracy. In order 
to do this, it is necessary to revive an independent civil society that is capable of active societal discussion. Media are in the centre of the process through the choices they make: Are they striving for the revival of Finnish political culture and public discussion, or merely legitimating the status quo?

\section{Note}

1. This article is based on a research project, which is part of the Power and Society in Finland research programme (2007-2010) funded by the Academy of Finland.

2. Figure from April 2010, see http://medianetti.helsinginsanomat.fi/english/

\section{References}

Ahlfors, B. \& Kolanen, R. \& Reuna, R. (1995) Valta murroksessa. Helsinki: Tammi.

Alapuro, R. (1999) 'Kertomus suomalaisista idän ja lännen välissä', in Löytönen, M. \& Kolbe, L. (eds.) Suomi. Maa, kansa, kulttuuri. Helsinki: SKS.

Alasuutari, P. (1996) Toinen tasavalta. Suomi 1946-1994. Tampere: Vastapaino.

Anderson, B. (1991) Imagined Communities: Reflections on the Origin and Spread of Nationalism. London: Verso.

Beck, U. (1999) Mitä globalisaatio on? Tampere: Vastapaino.

Davis, A. (2003) 'Whither Mass Media and Power? Evidence for a Critical Elite Theory Alternative', Media, Culture \& Society 25: 669-690.

Davis, A. (2002) Public Relations Democracy. Public Relations, Politics and the Mass Media in Britain. Manchester University Press.

Dubiel, H. (1990) 'Zivilreligion in der Massendemokratie', Soziale Welt, 41 Heft 2: 125-143.

Eskola, J. \& Suoranta, J. (1998) Johdatus laadulliseen tutkimukseen. Tampere: Vastapaino.

Etzioni-Halevy, E. (1999) Elites, Inequality and the Quality of Democracy in Ultramodern Society. International Review of Sociology (992. 239-250.

Fairclough, N. (2003) 'Critical Discourse Analysis in Researching Language in the New Capitalism: Overdetermination, Transdisciplinary and Textual Analysis’, in Young, L (toim.) Systemic Linguistics and Critical Discourse Analysis (2003).

Flyvbjerg, B. (2001) Making Social Science Matter. Why Social Inquiry Fails and How it Can Succeed Again. Cambridge: Cambridge University Press.

Foucault, M. (1978) The History of Sexuality I: An Introduction. New York: Pantheon.

Foucault, M. (1980) 'Powers and Strategies', in Colin G. (ed.) Power/Knowledge. Selected Interviews and Other Writings 1972-1977 by Michel Foucault. New York: Pantheon.

Foucault, M. (2000a) Truth and Power. Kirjassa Faubion, J.D. (toim.) Power. Essential Works of Foucault 1954-1984. Volume Three. New York: The New Press.

Foucault, M. (2000b) The Subject and Power. Kirjassa Faubion, J.D. (toim.) Power. Essential Works of Foucault 1954-1984. Volume Three. New York: The New Press.

Hay, C. \& Rosamond, B. (2002) 'Globalization, European Integration and the Discursive Construction of Economic Imperatives’, Journal of European Public Policy (9)2: 147-167.

Heikkilä, H. (1996) “Teemmepä kumman päätöksen tahansa...” EU-keskustelun rakentuminen valtavirtamediassa 1992-1994', in Kivikuru, U. (ed.) Kansa euromyllyssä. Helsinki: University Press.

Heiskala, R. (2006) 'Kansainvälisen toimintaympäristön muutos ja Suomen yhteiskunnallinen murros', in Heiskala, R. \& Luhtakallio, E. (eds.) Uusi jako. Miten Suomesta tuli kilpailukyky-yhteiskunta. Tampere: Gaudeamus.

Hirschman, A. O. (1994) 'Social Conflicts as Pillars of Democratic Market Society', Political Theory, (22)2: 203-218.

Ilmonen, K. (2006) 'Suomalainen kansalaisyhteiskunta ja yhteiskunnallinen muutos 1990-luvun lopulla', in Heiskala, R. \& Luhtakallio, E. (eds.) Uusi jako. Miten Suomesta tuli kilpailukyky-yhteiskunta. Tampere: Gaudeamus.

Ilmonen, K. (1998) 'Uudet ja vanhat yhteiskunnalliset liikkeet', in Ilmonen, K. \& Siisiäinen, M. (eds.) Uudet ja vanhat liikkeet. Tampere: Vastapaino.

Jallinoja, R. (2006) Perheen vastaisku: familistista käännettä jäljittämässä. Helsinki: Gaudeamus.

Juhila, K. (1999) Tutkijan positiot. Kirjassa Jokinen, A. \& Juhila, K. \& Suoninen, E.: Diskurssianalyysi liikkeessä. Tampere: Vastapaino. 
Kantola, A. (2002a) Markkinakuri ja managerivalta. Poliittinen hallinta Suomen 1990-luvun talouskriisissä. Helsinki: Loki.

Kantola, A. (2002b) 'Se keskustelu jäi käymättä - poliittinen eliitti ja talouskriisin julkisuus', in Kivikuru, U. (ed.) Laman julkisivut. Media, kansa ja eliitit 1990-luvun talouskriisissä. Helsinki: Palmenia-kustannus.

Keller, S. (1991) Beyond the Ruling Class. Strategic Elites in Modern Society. New Jersey: Transaction Publishers.

Kivikuru, U. (1996) 'Vastavirtaa ja sivupolkuja. Vaihtoehtodiskurssit jäivät kapeiksi ja erikoistuneiksi', in Kivikuru, U. (ed.) Kansa euromyllyssä. Helsinki: University Press.

Laclau, E. \& Mouffe, C. (1985) Hegemony and Socialist Strategy: Towards a Radical Democratic Politics. London: Verso.

Lampinen, O. (2002) 'Yhteiskuntatieteellisen tutkimuksen asema hallinnossa ja päätöksenteossa', Tiedepolitiikka (27)2: 15-21.

Lindholm, A. (2005) Maailmanparantajat. Globalisaatiokriittinen liike Suomessa. Helsinki: Gaudeamus.

Luostarinen, H. \& Uskali, T. (2006) 'Suomalainen journalismi ja yhteiskunnan muutos', in Heiskala, R. and Luhtakallio, E. (eds.) Uusi jako. Miten Suomesta tuli kilpailukyky-yhteiskunta? Helsinki: Gaudeamus.

Mattelart, A. (2002) 'An Archaeology of the Global era: Constructing a Belief', Media, Culture \& Society 24: 591-612.

Mattila, M. (2000) 'Valtioneuvosto. Suomen EU-politiikan määrittelijä', in Raunio, T. \& Wiberg, M. (eds.) EU ja Suomi. Unionijäsenyyden vaikutukset suomalaiseen yhteiskuntaan. Helsinki: Edita.

Olsen, J.P. (1996) 'Norway - Slow Learner - or Another Triumph of the Tortoise?', in Olsen, J. \& Peters, G.P. (eds.) Lessons from Experience. Oslo: Scandinavian University Press.

Paloheimo, H. (2002) 'Pääministerin vallan kasvu Suomessa', Politiikka (44)3: 203-221.

Potter, J. \& Wetherell, M. (1987) Discourse and Social Psychology. Beyond Attitudes and Behavior. Lontoo: Sage.

Ruostetsaari, I. (2003) Valta muutoksessa.Vantaa: WSOY.

Rustow, D.A. (1970) 'Transitions to Democracy: Toward a Dynamic Model', Comparative Politics (2)3: 337-363.

Schwartz, M.A. \& Lawson, K. (2005) 'Political Parties: Social Bases, Organization, and Environment', in Janoski, T. \& Alford, R.R. \& Hicks, A.M. \& Schwartz, M.A.: The Handbook of Political Sociology. States, Civil Societies, and Globalization. New York: Cambridge University Press.

Siisiäinen, M. (1998) 'Uusien ja vanhojen liikkeiden keinovalikoimat', in Ilmonen, K. \& Siisiäinen, M. (eds.) Uudet ja vanhat liikkeet. Tampere: Vastapaino.

Spinosa, C. \& Flores, F. \& Dreyfus, H.L. (1997) Disclosing New Worlds. Entrepreneurship, Democratic Action, and the Cultivation of Solidarity. Cambridge: MIT Press

Törrönen, J. (1997) 'Intohimoinen teksti - pysäytetty kertomus suostuttelun makrorakenteena', in Sulkunen, P. \& Törrönen, J. (eds.) Semioottisen sosiologian näkökulmia. Tampere: Gaudeamus.

Väliverronen, E. (1993) 'Diskurssien verkossa. Joukkoviestimet, julkisuus ja valta', Tiedotustutkimus 16: 1. Väyrynen, R. (1999) Globalisaatio ja Suomen poliittinen järjestelmä. Helsinki: Sitra/Taloustieto.

Wapner, P. (1994) ‘Environmental Activism and Global Civil Society’, Dissent 41: 23.

Willman, A. (2001) Yhteistyön ristiriitaiset puhetavat. Diskurssianalyyttinen näkökulma luokanopettajien tulkintoihin tiimityöstä. Oulu: Acta Universitatis Ouluensis Scientiae Rerum Socialium.

LOTTA LOUNASMERI, MSc. (Soc.Sci.), MSc. (Econ.), Research Associate, Media and Communication Studies, Department of Social Research, University of Helsinki, lotta. lounasmeri@helsinki.fi 